\title{
SUBJECT FIELD OF EXPERIENCE INTENTIONALITY: PHENOMENOLOGICAL ANALYSIS
}

GEIKO S. M. , PhD, Associate Professor of the Department of Philosophy and International Communication at the National University of Life and Environmental Sciences of Ukraine

E-mail:svt.geyko@gmail.com

LAUTA O. D, PhD, Associate Professor of the Department of Philosophy and International Communication at the National University of Life and Environmental Sciences of Ukraine

E-mail: elena.lauta@gmail.com

Abstract. The article is devoted to reveal of specifics of phenomenological approach to problem of experience understanding, especially its' intentional nature. It is established that phenomenological explication of experience reveals its' connection with problem of Another.

Key words: phenomenology, experience, reflexion, intentionality, Another, reduction, noema, apperception.

Introduction. The transformation of the classical style of philosophizing led to a rethinking of the categorical apparatus. In particular, a new paradigm of understanding the concept of "experience» is being formed. If in classical rationalism it had an epistemological load, then in nonclassical philosophy new perspectives of its interpretation open up. Thus the phenomenological tradition of philosophizing, starting from the critique of naturalism and psychologism of previous philosophy, postulates the intentional nature of experience.

Analysis of recent researches and publications. Its founder E. Husserl, as well as R. Ingarden, B. Waldenfels, A. Schutz, and M. Merleau-Ponty worked on the problem of experience within this area.

Purpose. The task of our study is to identify the specifics of the phenomenological approach to the problem of understanding experience, in particular its intentional nature.

Methods. To identify the specifics of this basic concept and its structure, phenomenology offers a study of the inner layers of experience, which has gone through various types of phenomenological reductions and lost all apophantic features and psychological

interpretation. It would not be wrong to say that experience is the form of life that directly precedes, generates, and directs the process of cognition. Any knowledge comes from experience, and any knowledge is contained in experience. Accordingly, there are no ideal subjects. There is also no knowledge other than that which comes from experience. Experience is the highest kind of any knowledge. Without experience there is no science. But what is «experience»? This means sensory, «external» experience: vision, sensation, etc. As a last resort, another type of experience is recognized, namely the so-called «reflection» or, if you will, «internal» perception [3]. In this regard, B. Waldenfels notes: «Experience primarily means an event in which the "things themselves» are revealed, respectively. Experience means the process in which meaning is formed and articulated and in which things acquire structures and images» [1, 13-14].

Results. What is meant by phenomenology, which has its origins in Husserl? First of all, purely formally, this means a special way of considering philosophical problems, as well as a very special technique of linguistic presentation of the results obtained by such a way of relating to the world or 
viewing the world, in the phenomenological method. R. Ingarden believes that not all people who have become phenomenologists use it in the same sense. There are different versions of this method - depending on the talent and mindset of the relevant phenomenologists.

But phenomenology can be considered in another sense, namely as a set of statements or as a system of theories that are the result of a phenomenological method of consideration. And in this case in the first place is the phenomenology of $E$. Husserl as a separate topic in itself, which differs in various essential respects from the phenomenology of $M$. Scheler, or from the so-called «Munich phenomenology» (A. Pfender, M. Geiger, D. Hildebrand, etc.), or, finally, from the philosophy of $\mathrm{M}$. Heidegger. The big difference, in particular, is that young phenomenologists not only repeat what was said by the father of phenomenology, but also seek to use his method to move forward, and for this reason they do not accidentally come to results that differ from those which E. Husserl would like to see. In phenomenology. Husserl's notion of experience comes to the fore in the context of the problem of intentionality and the original phenomenological maxim: "Back to things themselves», which, according to the Polish philosopher R. Ingarden, can be interpreted: «Back to the original, direct experience!». "Experience» is a German word, «initially giving experience» is already a technical term, and it is difficult to say with sufficient precision what this «initial» should mean in the end. This initial, real experience confirms the "right» of certain cognitive outcomes; here the «right» to truth, to significance must derive its legal justification from the limit, originally giving contemplation. It is the source of significance or truth. This should simply be taken for granted. What is given from the beginning must be accepted, says Husserl; there is nothing more to ask and especially nothing to doubt. That is, there is at least one area (objects that Husserl would later say that it is impossible to ask questions or doubt here in the sense that doubt is absurd. This is a source of knowledge, which will later be called «immanent perception») [3].

The first principle, which Husserl later called the uprinciple of all principles», and which he put forward, states: There is no knowledge without experience! What is felt in experience must first be comprehended in experience, and everything else must be obtained and developed from experience, the marginal grounds must be substantiated in experience. «Experience» was understood as nothing more than the possession of "feelings» that are causally generated by physical stimuli. But, on the other hand, what is specifically given in sensory perception, and at the same time cannot be identified with "feelings», was designated as something that comes from «experience» [3].

It is not surprising that the main categories of this concept are the obvious and self-giving, the detection of which involves intentional-constitutive analysis of consciousness. Waldenfels makes the following reasoning: «A pervasive event of experience is what Husserl calls intentionality. Regardless of the problematic preconditions of the doctrine of consciousness and the rather narrow data of language analysis, intentionality means that something appears to us as something, ie in a specific sense, a specific image, structure or rule» $[1,14]$. Instead, the founder of the phenomenological doctrine himself defined intentionality as «the general theme of objectively adjusted phenomenology» [2, 183]. Analyzing experiences, Husserl pointed out that all of them are in some way relevant to intentionality, although not all of them can be considered truly endowed 
with such a mode of being in the sense in which we speak of another indisputable aspect inherent in experience - its temporal dimension. Thus, according to Husserl, intentionality is that which reveals consciousness in a clear sense and justifies the characterization of the whole flow of experience as a whole as a certain unity of the flow of consciousness. Intentionality demonstrates a fundamental rethinking by phenomenology of the properties of experience and modes of perception, as a result of which it follows that any act of consciousness is always a perception of something, such as a thing. In this case, E. Husserl cites as examples of judgments that cover a certain state of affairs; assessment, which always assumes a certain value situation; desire, which undoubtedly relates to certain circumstances, etc. He states: "Action is directed to some action, behavior - to action, love - to what is beloved, joy - to joy» [2, 185]. At the same time, Husserl notes that there is a certain background as a variety of subjects, among which stands out this cognitively perceived fact. At the same time, Husserl draws attention to the experience of the background of relevance, what he calls the "trend" of taste, judgment, desire, etc. - at various stages of the more distant or closer background. It means that to feel pleasure, to desire, to appreciate something is possible in the specific sense of "realization» and it happens thanks to the Self which is «vital» in similar accomplishment (that is, for example, actually suffers in the moment of sorrow), however, can be so that all ways of consciousness of this kind already "suggest something", emerge in the «background», not yet realized. But according to its own essence, all irrelevancies of this kind, nevertheless, are "consciousness of something". However, as Husserl rightly points out, the concept of «consciousness of something», despite the fact that it is supposedly self-evident, at the same time remains largely problematic and incomprehensible. Therefore, to clarify such a fundamental transcendental structure as an intentional act, the founder of phenomenology resorted to the analysis of noetic-noematic connection, distinguishing real and intentional components of experience, paying attention to the fundamental difference between these aspects, which allows to move from natural to phenomenological guidelines.

E. Husserl argues as follows: "Any intentional experience due to its noetic moments is a noetic experience; this means that its essence is to hide in itself something like "meaning», to hide even a multifaceted meaning and then, on the basis of such a meaning, to make other accomplishments, which thus become «meaningful» [2, 197]. An example of such a noetic moment according to Husserl is the orientation of the pure "|l» is gaze to the object which is implied by the endowment of a certain meaning, and then to its grasping and fixation at a time when the gaze has already turned to other objects entering its field. perception; This also includes the activity of explication, mutual grasping, acceptance of various positions of faith, foresight, appreciation, and so on. Correlative noematic filling corresponds to such noetic filling of experience. Each perception has its own noem, on nothing - the meaning - that is, what is perceived as such. Similarly, any recollection carries in itself the recollection as such along with what is conscious in it; judgment, in turn, possesses as such what is in question, satisfaction with what it brings, and so on.

The noematic correlate, which in this case Husserl identifies with meaning, should be understood as immanently captured in the experience of perception, judgment, pleasure, that is, as it is offered to us by the experience itself. To 
clarify this situation, the philosopher cites perhaps the most famous example from the «ldeas»: "It is obvious that perception and the accompanying pleasure are not the same as what is perceived and causes pleasure» [2, 199]. Analyzing the act of contemplation, the phenomenologist does not care whether something corresponds to him in the "very» reality, he does not say anything about the existence or non-existence of the perceived thing, but draws attention to the fact that even after the phenomenological reduction everything remains, so to speak as it was. Similarly, the pleasure obtained is the same, which is caused accordingly. Thus, phenomenological analysis involves immersion in the problems of essence, what is what is perceived as such, what essential moments it hides in itself, as a specific noema.

Examining the structure of the intentional act, Husserl also draws attention to the attentional shifts, which, although already presupposing the existence of a noetic nucleus and inherent in its various aspects, do not in themselves change the corresponding noematic content and, importantly, still modify the experience in as a whole both from the noetic, and from the noematic party. As Husserl notes in this regard: "Within this aggregate field of potential noes and corresponding noetic objects, we then look at some whole, for example, at a tree that is perceptually present, then at its individual parts and moments, then at something that is nearby, then on some complex relationship or event. Suddenly we pay attention to an object of recollection that suddenly "comes to mind" - instead of following the noes of perception, which in a holistic, albeit variously divided continuum, constitutes for us a constantly emerging world of things. Our view, through the noes of remembrance, passes into the world of memories, wanders in it, or then passes through memories of other degrees, into purely fantastic worlds, and so on» [2, 205].

In general, in the
phenomenological analysis of consciousness, at least four leading functions of intentionality can be distinguished, as S. Kosharny did: objectifying, identifying, connecting, and constitutive. In his view, the objectifying function of intentionality is that it sends phenomenal data, which are integral components of the flow of consciousness, to «intentional objects». They are usually accessible only by means of guillotine (sensory) data, and this function of intention presupposes their correlation with the object, which itself does not act as a part of the intentional act. Equally important is the identifying function of intentionality, which is to fix a variety of consecutive guillotine data on the same subject equivalents or poles of meaning. Without this property, the subject would have nothing but a variegated and intrinsically diverse variety of perceptions, a sequential flow of perceptions that are similar but never identical (that is, those that relate to the same subject). In this case, the intention performs the function of synthesis and identification of the conscious, through which various aspects, types, perspective shades of perception and temporal stages of awareness of the experience of the object are combined into a single whole, integrated into an identical semantic core, focusing on. In this case, we understand that each aspect of an identical object refers to the related parties, which form, so to speak, the semantic horizon of this object. For example, in the visual perception of something, the frontal view of the front of the object refers to its background, in addition to which, there is also the top and bottom, which is consistent due to the intentionality of a certain integrity. Thus begins the process of unfounded expectations for further intentional experiences, which may or may not be 
realized in the future development of our experience, but which are clearly outlined in the current data.

Thus, Husserl recognizes the need to distinguish intentional acts, to distinguish them, characterizing two different ways of relation of expression to the substantive meaning implied in it, as well as to draw boundaries in these acts between simple intentions of meaning and their contemplative execution (meaning). In this case, we are talking about those acts of experiencing something, which, so to speak, blindly refer to intentional objects, when we just think about them and do not have a clear idea of what they look like, what they look like. In the second case we are dealing with acts of intentional experiences that fill the empty cognitive forms of such intentions with contemplative content, as happens, say, in imagination, fantasy, or in the same perception. As the researcher of Husserl S. Kosharny notes: purpose "[4, 49].

Husserl's reasoning about the intention and intentionality of consciousness can be summarized by describing a component of any conscious act responsible not only for referring to the intended object, but also for interpreting or revealing the meaning of these raw materials in such a way that the whole object appears for our consciousness, first, as the establishment of unity between the subject referents of several intentional acts, in which the same thing manifests itself in different aspects, sections and angles; secondly, as a connection in the subject-semantic unity of the various stages of the contemplative realization of the definite intention of consciousness; and thirdly, as an intentional constitution of the meaning of the object that is meant. Thus, the result of intentional analysis of the processes of our world consciousness is always to clarify the semantic picture of the world, the semantic structure of reality, the disclosure of objective meanings of life - empirical phenomena of everyday life or theoretical idealizations and conceptual abstractions of science, material things or logical laws. cognition or relationships of cultural phenomena.

The problem of phenomenological understanding of experience intersects with the founder of phenomenology with the theme of the Other, which plays an extremely important role in modern phenomenology. For E. Husserl, it not only appeared as an opposition to accusations of solipsism, but also marked a new, somewhat different from "ldeas» approach and, accordingly, the transition from static (analysis of the structure of the intentional act) to dynamic phenomenology, and, consequently, to issues of the World of Life, historicity and factuality of experience. Despite the fact that all these problems were developed by Husserl in his latest works: "The Crisis of European Science and Transcendental Phenomenology» and "Experience and Judgment», nevertheless, the problem of the Other and the Experience of the Stranger, which served as the impetus for Merleau-Ponty, Sartre, Waldenfels, Schutz and many other philosophers, was violated in the famous Fifth Cartesian Meditation: «... I experience the world with its existing "others» and, according to the meaning of this experience, not as so to speak, my own synthetic product, but as an intersubjective world alien to me, existing for everyone and available to everyone in their objects» [5].

Husserl is primarily interested in whether the givenness of the Other Self differs from the way given by objects, because alter Egos are manifested within implicit and explicit intentions based on my transcendental Ego in the same way and in the same way as ordinary objects. 3-on this occasion, he notes: «For example, in experience, I know "others» as really existing, in the changing consistent varieties of experience, and I know them, on the one hand, as objects 
of the world. In this case, they act not just as natural physical things, although, in some respects, as such as well. After all, they are known in experience and as those who control the natural lamas adjusted to them through the psyche ... On the other hand, I at the same time know them in experience as related to this world subjects, as subjects, who know this world in experience, and the same world that I know myself, and who know me as one who knows this world and the "others» existing in it [5].

However, who is this Other, and do Nature and the World, constituted in Ego, contain objectivity at all? According to Husserl, the way of giving the Other should be considered as the meaning of the "coordinated experience of the Stranger», and which is constituted not only in certain intentions, but also in syntheses, motivations. Synthesis is related in the system of Husserl's phenomenology to the unification of consciousness into a single stream, motivation within the knowledge of the world is a prerequisite or refusal at any stage of knowledge to accept the idea or knowledge of the final, and provoke the transition from one experience to another. from enlightened facts to their various shades.

Thus, using the above-mentioned properties of intentionality, synthesis, motivation, we can conclude that the "meaning of the Other» has both similarities with the given subject and differences. First of all, it is the psychophysical domination in the natural body that belongs to the Other, as well as the fact that he is similar to me in the acts of cognition and reflection. Another question arises: can the Other or the alter Ego be given to me in the same way that I am given to myself? After all, having said that the Other is really real, Husserl has already endowed him with a certain being, just as he has endowed a being with the actual «l». This problem refers us again to the "Ideas», where it was said that in the knowledge of things such a direct given is the goal and in principle is achievable, although never absolutely (however, in a certain perspective). its achievement is the achievement of truth, which Husserl characterizes as obvious. As for other selves, the alter ego is not attainable in a way of direct or original self (which works in inner experience or self-perception). An important point in understanding Alter Ego is that Husserl emphasizes his role as "the subject of this world». Thus, the world itself is revealed together with the concept of Others, it is not predetermined, but opens in the process of cognition, which is always incomplete, motivates for further clarification. How the world of other selves differs from the world of objects, as Husserl writes as follows: Husserl emphasizes that apperception is not a conclusion in reasoning by analogy and is not a mental act at all, however, it intentionally refers us in the perception of a particular object to some the primary founding act, in which an object with a similar meaning was first constituted. In Husserl's view, even the things of this world that are not known to us are generally known in terms of their type: "We have seen something similar before, though not exactly this thing that is here. Thus, any everyday experience hides in its prepredicative perception of the subject as having a similar meaning, based on the analogy of transferring the originally established subject meaning to a new case. In addition, the world of experience includes objects with spiritual predicates, which according to their own origin and meaning send us to the subjects, and often to "other» subjects and their active constitutive intentionality: such are all objects of culture (books, all possible devices and mechanisms, etc.), which, however, contain the meaning of the experience of this existence for everyone» [5].

Thus from these considerations follows an interesting idea of the duality of the intersubjective world, which, on the 
one hand, for each acts as a world of its own subjective-relative experience, on the other hand, exists in relation to all subjects of cognition in experience and their world phenomena. According to Husserl, the Other Self is indeed united by some world, but it does not simply "exist in itself», but receives its being as a space between me and the Other, that is, it is the space of our physical and spiritual interaction in the fifth meditation in Husserl appears the problem of bodily intentionality, which manifests itself in the modes «l can» and «I do»); a space that is never complete and is always redefined based on the nature of that interaction. To clarify this thesis, it is necessary to generalize something. First of all, the Other is a necessary condition for the existence of the world, and it is a fact from which to proceed. The other does not lead me to himself (as was the case, for example, with Hegel) and is not one of the parties or manifestations of the already given and always existing existence of the world (which is characteristic of Plato's philosophy). The other is not defined in the same way as I am, but at the same time, as Husserl notes: «... The other points to myself; The other is my own reflection, and at the same time it does not turn out to be so, it is my own analogue, and, again, an analogue not in the usual sense of the word» [5].

$\begin{array}{llr}\text { Conclusion. } & \text { Thus, } & \text { the } \\ \text { phenomenological } & \text { tradition } & \text { of } \\ \text { philosophizing } & \text { criticizes } & \text { the } \\ \text { epistemological } & \text { understanding }\end{array}$
experience that was formed in classical rationalism. Already the founder of the phenomenological direction E. Husserl departs from the understanding of experience as a set of sensations. Discovering the intentional nature of experience allows phenomenology to discover its rootedness in the living world. Phenomenological analysis of experience reveals the affinity of this problem with the theme of the Other. Because the experience of the Other differs from the given of things, which allows a person to constitute the experience not only in certain intentions, but also in syntheses, motivations.

Список використаних джерел

1. Вальденфельс Б.

Топографрія Чужого. Студії до феноменології Чужого. (пер. 3 нім., післямова В. Кебуладзе). ППС, 2002, 2004. 206 c.

2. Гуссерль Э. Идеи к чистой феноменологии и феноменологической фрилософфии. Изд.: М.: Территория будущего, 2005. $464 \mathrm{c}$.

3. Ингарден. Р. Введение в феноменологию Эдмунда Гуссерля // (перевод А. Денежкина и В. Куренного). М.: Дом интеллектуальной книги, 1999.

4. Кошарний C.

О. Феноменологічна концепція фолософрії Е.Гуссерля: критичний аналіз. К. : Український Центр духовної культури, 2015. С. 244-287.

5. Шпарага Олена. Феноменология опыта: опыт как “почва и горизонт" познания. URL: http://www.ruthenia.ru/logos/number/200 1 2/08 2 2001.htm

\section{References}

1. Val'denfel's B. (2002). Topografiya Chuzhogo. Studii k fenomenologii Chuzhogo. [Topographie eines anderen. Studien zur Phänomenologie des Fremden]. PPS. 206 s. [in Ukrainian]

2. Gusserl' E. (2005). Idei k chistoy fenomenologii i fenomenologicheskoy filosofii. [Ideen für reine Phänomenologie und phänomenologische Philosophie]. Territoriya budushchego. 464 [in Russian].

3. Ingarden. R. (1999). Vvedeniye $v$ fenomenologiyu Edmunda Gusserlya. [Innforing in Edmund Husserls Fenomenologi]. Dom intellektual'noy knigi. [in Russian]. 
4. Kosharnyy S. (2015). Fenomenolohichna kontseptsiya filosofiyi E. Husserlya: krytychnyy analiz. Ukrayins'kyy Tsentr dukhovnoyi kul'tury. S. 244-287.
5. Shparaga Yelena. Fenomenologiya opyta: opyt kak "pochva i gorizont". Retrieved from http://www.ruthenia.ru/logos/number/200 $12 / 082$ 2001.htm [in Russian]

\section{ПРЕДМЕТНЕ ПОЛЕ ІНТЕНЦІОНАЛЬНОСТІ ДОСВІДУ: ФЕНОМЕНОЛОГІЧНИЙ АНАЛІЗ}

Гейко С. М., Лаута О. Д.

Стаття присвячена виявленню специфріки феноменологічного підходу до проблеми розуміння досвіду, зокрема його інтенціональної природи. Виявлено, що френоменологічна експлікація досвіду відкриває його зв'язок з проблемою Іншого. Трансформація класичного стилю фрілософуування спричинила переосмислення категоріального апарату. Зокрема, формується нова парадигма розуміння поняття «досвід». Якщо в класичному раціоналізмі воно мало гносеологічне навантаження, то в некласичній фрілософрії відкриваються нові перспективи його інтерпретації. Так френоменологічна традиція фрілософування, відштовхуючись від критики натуралізму та психологізму попередньої фрілософії постулює інтенціональну природу досвіду. Для виявлення специфріки цього засадничого поняття та його структури феноменологія пропонує дослідження внутрішніх пластів досвіду, який пройшов через різні види феноменологічних редукцій $i$ позбавився всіх апофрантичних рис та психологічного тлумачення. Досвід є тією формою життя, котра безпосередньо передує процесу пізнання, породжує та спрямовує його. Будь-яке знання, походить з досвіду, і будь-яке знання міститься 8 досвіді. Під френоменологією Е. Гусерля розуміється особливий спосіб розаляду фрілософьських проблем, а також абсолютно особлива техніка мовного викладу результатів, які були отримані при такому способі ставлення до світу або розгляду світу, тобто френоменологічний метод.

Ключові слова: феноменологія, досвід, ресрлексія, інтенціональність, Інший, редукція, ноема, апперцепція. 